\title{
PARTIAL REPLACEMENT OF CEMENT BY QUARRY DUST
}

\author{
B. Manoj $^{1}$, G. Laxmi Prasanna ${ }^{2}$, D. Sai Krishna ${ }^{3}$, B. Siva Sankar Reddy ${ }^{4}$, T. Vamsi Krishna ${ }^{5}$, \\ M. Surendra Reddy 6 \\ ${ }^{1}$ Professor, Civil Department, QIS College of Engineering \&Technology, India \\ ${ }^{2}$ Assistant Professor, Civil Department, QIS College of Engineering \&Technology, India \\ ${ }^{3}$ Civil Department, QIS College of Engineering \&Technology, India \\ ${ }^{4}$ Civil Department, QIS College of Engineering \&Technology, India \\ ${ }^{5}$ Civil Department, QIS College of Engineering \&Technology, India \\ ${ }^{6}$ Civil Department, QIS College of Engineering \&Technology, India
}

\begin{abstract}
Quarry dust a waste product obtained from stone crushing. The aim of experimental investigation is to replace cement with quarry dust. In this test the replacement of cement in concrete with quarry dust are 0\%,10\%,20\%,25\%,30\%,40\% and $M_{30}$ grade concrete cubes of size $150 \mathrm{~mm} \times 150 \mathrm{~mm} \times 150 \mathrm{~mm}$ were cast for finding its compressive strength. From the experimental studies it is observed that by $25 \%$ of partial replacement of cement with quarry dust improved hardened concrete properties.
\end{abstract}

Keywords: Quarry dust, cement, water, aggregates.

\section{INTRODUCTION}

Quarry dust is a waste product obtained from quarrying. It can be used as an effective filler material instead of cement. In the present study, the properties of concrete using quarry dust were investigated.

Table 1: Physical Properties of Quarry dust

\begin{tabular}{|l|l|l|}
\hline S.No & Particulars & Properties \\
\hline 1 & Colour & Gray \\
\hline 2 & Shape texture & Irregular \\
\hline 3 & Mineralogy & Non crystalline \\
\hline 4 & Particle size & $>45$ micron \\
\hline 5 & Odour & Odourless \\
\hline 6 & Specific gravity & 2.3 \\
\hline
\end{tabular}

Table 2: Chemical Properties Of Quarry Dust

\begin{tabular}{|l|l|l|}
\hline S.NO & Particulars & Proportion \\
\hline 1 & Silicon dioxide & $86.94 \%$ \\
\hline 2 & Aluminium oxide & $0.2 \%$ \\
\hline 3 & Iron oxide & $0.1 \%$ \\
\hline 4 & Calcium oxide & $0.3-2.2 \%$ \\
\hline 5 & Magnesium oxide & $0.2-0.6 \%$ \\
\hline 6 & Sodium oxide & $0.1-0.8 \%$ \\
\hline 7 & Potassium oxide & $2.1-2.30 \%$ \\
\hline
\end{tabular}

\section{Selection of W/C Ratio}

$\mathrm{Max}$ W/C RATIO $=0.45$ [from IS 456:2000]

Adopt $=0.42$

\section{Fine Aggregate}

In this concrete mixture sand is the fine aggregate. Sand is a naturally occurring granular material composed of finely divided rock and mineral particles. In terms of particle size as used by geologists, sand particles range in diameter from $0.0625 \mathrm{~mm}$ (or $1 / 16 \mathrm{~mm}$ ) to $2 \mathrm{~mm}$.

\section{Course Aggregate}

Uncrushed gravel or stone which is the result of natural disintegration and crushed gravel or stone are usually called the "Coarse Aggregates".As mentioned earlier, coarse aggregates are stones that are retained on $4.75 \mathrm{~mm}$ sieve.

\section{Water}

As per IS 456:2000, water used for both mixing and curing should be free from injurious amount of deleterious materials. Portable water (tap water) is generally considered satisfactory for mixing and curing concrete.

\section{Cement}

In this experiment we use, which cement has good fineness and good normal consistency. In this experiment we use OPC 43 grade cement. 


\section{Mix Proportions}

\begin{tabular}{|l|l|l|l|l|l|l|l|l|}
\hline $\begin{array}{l}\text { SI } \\
\text { No }\end{array}$ & $\begin{array}{l}\text { Mix } \\
\text { Designation }\end{array}$ & $\%$ QD & W/C & $\begin{array}{l}\text { Kement } \\
(1 \text { Cubic } \\
\text { meter })\end{array}$ & $\begin{array}{l}\text { Fine } \\
\text { Aggregate Kg } \\
(1 \text { Cubic } \\
\text { meter })\end{array}$ & $\begin{array}{l}\text { Quarry } \\
\text { dust Kg } \\
(1 \text { Cubic } \\
\text { meter })\end{array}$ & $\begin{array}{l}\text { Coarse } \\
\text { Aggregate Kg } \\
(1 \text { Cubic meter })\end{array}$ & $\begin{array}{l}\text { Water } \\
\text { in lit }\end{array}$ \\
\hline 1 & M30 & $0 \%$ & 0.42 & 353 & 980 & 0 & 1120 & 148 \\
\hline 2 & M30 & $10 \%$ & 0.42 & 317.7 & 980 & 35.3 & 1120 & 191.58 \\
\hline 3 & M30 & $20 \%$ & 0.42 & 282.4 & 980 & & 1120 & 191.58 \\
\hline 4 & M30 & $25 \%$ & 0.42 & 264.75 & 980 & 88.25 & 1120 & 191.58 \\
\hline 5 & M30 & $30 \%$ & 0.42 & 247.1 & 980 & 105.9 & 1120 & 191.58 \\
\hline 6 & M30 & $40 \%$ & 0.42 & 225.5 & 980 & 122.5 & 1120 & 191.58 \\
\hline
\end{tabular}

\section{MIX DESIGN}

In this mix design we prepare $\mathrm{M}_{30}$ grade Concrete using cement, sand, course aggregate, water \& some percentage of quarry dust which replaces the cement. In this experimental investigation concrete cubes of $150 \mathrm{~mm} \times 150 \mathrm{~mm} \times 150 \mathrm{~mm}$ were casted and cured for $7,14 \& 28$ days conventionally. In this experimental investigation cubes casted with partial replacement of cement by quarry dust with percentages $0 \%$, $10 \%, 20 \%, 25 \%, 30 \%$, and end up with $40 \%$. M30 grade of concrete is designed according to IS: 10262:2009 code provisions. Compressive strength of the cubes were casted and cured for 7, $14 \& 28$ days. From the test data the results were presented in table 3 and also plot is shown in chart1.

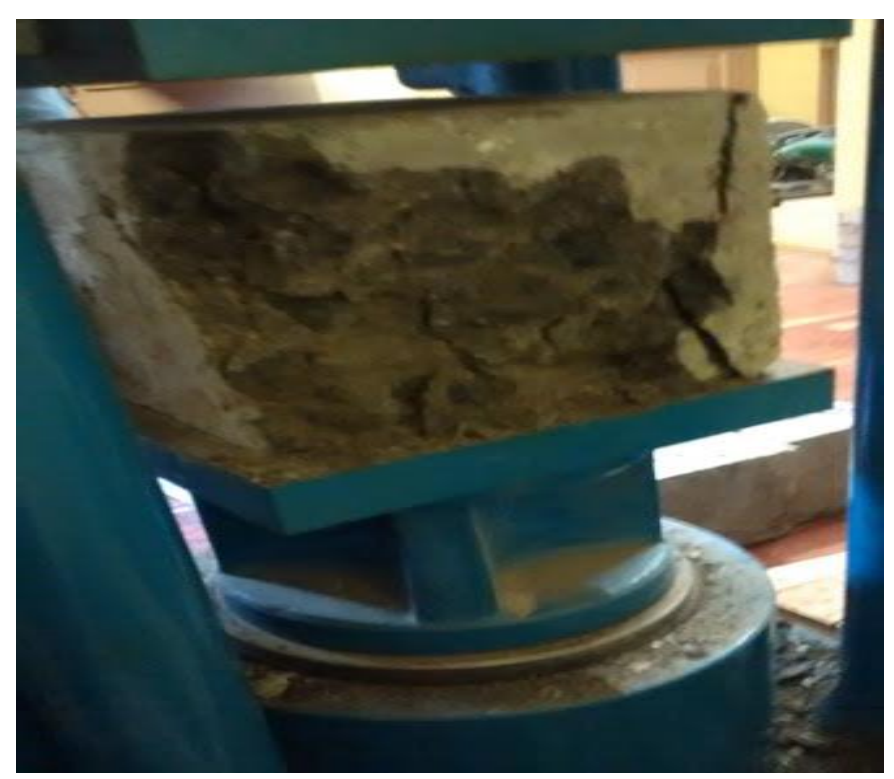

Fig 1: Compresive Strength

\section{RESULTS}

Table 3: Compressive Strength

\begin{tabular}{|l|l|l|l|l|}
\hline S.NO & Grades & $\begin{array}{l}\text { C.S for 7 } \\
\text { days }\end{array}$ & $\begin{array}{l}\text { C.S for } \\
\text { 14 days }\end{array}$ & $\begin{array}{l}\text { C.S for } \\
\mathbf{2 8} \text { days }\end{array}$ \\
\hline 1 & M30(0\%) & 35 & 37 & 36 \\
\hline 2 & M30(10\%) & 36.5 & 36.9 & 36 \\
\hline 3 & M30(20\%) & 37.5 & 36.9 & 38.5 \\
\hline 4 & M30(25\%) & 41.5 & 40.5 & 41.5 \\
\hline 5 & $\mathrm{M} 30(30 \%)$ & 36 & 37.5 & 35 \\
\hline 6 & M30(40\%) & 27.9 & 27 & 27.5 \\
\hline
\end{tabular}
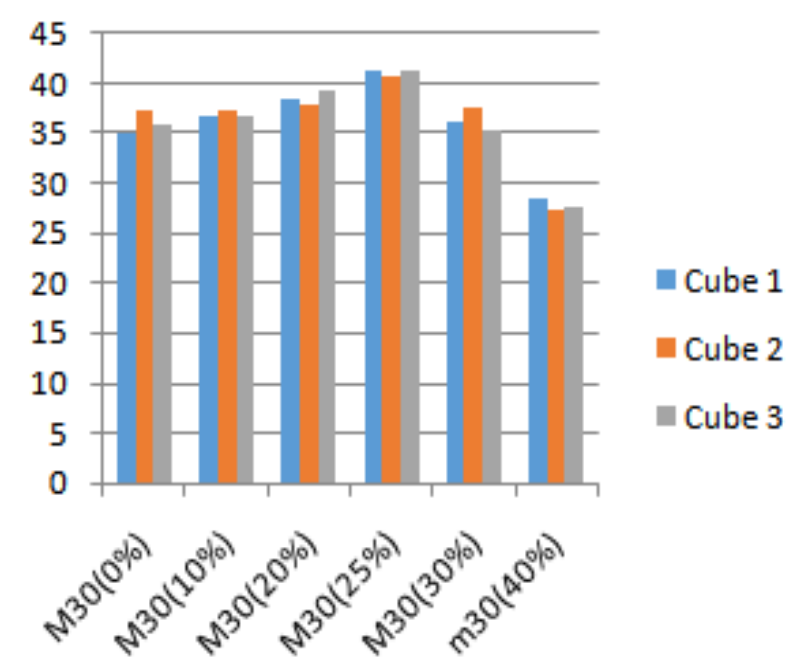

Chart 1: Compressive Strength of cubes

\section{Abbreviations:}

Cube $1=7$ days curing

Cube $2=14$ days curing

Cube $3=28$ days curing

$\mathrm{CS}=$ Compressive strength

$\mathrm{QD}=$ Quarry dust 


\section{CONCLUSION}

The analysis of experimental investigation data shown that addition of $25 \%$ quarry dust with cement gives the compressive strength of $41.5 \mathrm{~N} / \mathrm{mm}^{2}$ when compared to conventional i.e. without any replacement of quarry dust. From the above test results, It is clearly observed that addition of quarry dust up to certain extent will increase the compressive strength of concrete.

\section{REFERENCES}

[1] Concrete technology by Ms. SHETTY. and IS 456:2000.

[2] S.Subhashini on "use of quarry dust in concrete design".(2016)

[3] Praveen M (Feb 2014) Bijapur: Recent Trends in Replacement of Natural Sand With Different Alternatives"(IOSR-JMCE) e-ISSN: 2278-1684, pISSN: 2320-334X PP 59-6

[4] B.Sukumar, K. Nagamani, and R. Srinivasa Raghavan, "Evaluation of strength at early ages of self-compacting concrete with high volume fly ash," Construction and Building Materials, vol. 22, no. 7, pp. 1394-1401, 2008.

[5] D. W. S. Ho, A. M. M. Sheinn, C. C. Ng, and C. T. Tam, "The use of quarry dust for SCC applications," Cement and Concrete Research, vol. 32, no. 4, pp. 505-511, 2002.

[6] H. A. F. Dehwah, "Corrosion resistance of selfcompacting concrete incorporating quarry dust powder, silica fume and fly ash," Construction and Building Materials, vol. 37, pp. 277-282, 2012.

[7] I.B.Muhit, M. T. Raihan, and M. Nuruzzaman, "Determination of mortar strength using stone dust as a partially replaced material for cement and sand," Advances in Concrete Construction, vol. 2, no. 4, pp. 249-259, 2014.

[8] J. O. Ukpata and M. E. Ephraim, "Flexural and tensile strength properties of concrete using lateristic sand and quarry dust," ARPN Journal of Engineering and Applied Sciences, vol. 7, pp. 324-331, 2012.

[9] M. N. Soutsos, K. Tang, and S. G. Millard, "Concrete building blocks made with recycled demolition aggregate," Construction and Building Materials, vol. 25, no. 2, pp. 726-735, 2011.

[10] M. R. Chitlange and P. S. Pajgade, "Strength appraisal of artificial sand as fine aggregate in SFRC," ARPN Journal of Engineering and Applied Sciences, vol. 5, no. 10, pp. 34-38, 2010.

[11] M. Devi and K. Kannan, "Analysis of strength and corrosion resistance behavior of inhibitors in concrete containing quarry dust as fine aggregate," Journal of Engineering and Applied Sciences, vol. 6, no. 11, pp. 124-135, 2011.

[12] R. P. Nanda, A. K. Das, and N. Moharana, "Stone crusher dust as a fine aggregate in concrete for paving blocks," International Journal of Civil and Structural Engineering, vol. 1, no. 3, p. 613, 2010. 